Огляди літератури, оригінальні дослідження, погляд на проблему, ювілеї

УДК 616.01-008.46/-005.1+616.365-008.64]-06:616.126-12

DOI 10.11603/1811-2471.2018.v0.i2.8936

\title{
ПОРУШЕННЯ КИСНЕВОГО ЗАБЕЗПЕЧЕННЯ ПЕРИФЕРІЙНИХ ТКАНИН ПРИ АНЕМІЇ ХРОНІЧНИХ ЗАХВОРЮВАНЬ
}

\author{
๑А. І. Хоміцька, А. О. Боб, Г. Г. Кміта, Р. Й. Вибирана, Л. Т. Крамар, М. Є. Гаврилюк \\ ДВНЗ «Тернопільський державний медичний університет імені І. Я. Горбачевського МОз Украӥни», \\ Тернопільська університетська лікарня
}

PЕзЮМЕ. У статті наведено оцінку показників оксигенації артеріальної і венозної крові у 37 хворих на хронічну серцеву недостатність та анемію. Обгрунтовано доцільність визначення параметрів оксигенації артеріальної і венозної крові у даної категорії хворих.

КЛючовІ СлОВА: анемія хронічних захворювань; хронічна серцева недостатність; оксигенація артеріальної крові; оксигенація венозної крові.

Вступ. За даними національних реєстрів та епідеміологічних досліджень різних європейських країн, поширеність хронічної серцевої недостатності (CH) серед дорослого населення $\epsilon$ досить високою і коливається в межах 1,5-5,5 \% [1, 3]. Приблизно у 40 \% пацієнтів, госпіталізованих з приводу хронічної СН, діагностують вторинну анемію, яка $\epsilon$ предиктором несприятливого прогнозу у хворих із серцево-судинними захворюваннями [2, 4]. Відомо, що в ефективності функціонування системи транспортування кисню в організмі провідна роль належить функціональній здатності серцевосудинної системи та системи гемостазу $[5,6]$, а тому пошук діагностики порушень кисневого забезпечення організму на сьогодні $\epsilon$ досить актуальною проблемою.

Матеріал і методи дослідження. Обстежено 73 хворих на хронічну СН. Вік хворих становив від 41 до 78 років, в середньому $(57,3 \pm 3,6)$ років. До 1 групи увійшли 36 хворих на хронічну $\mathrm{CH}$, а 2 групу склали 37 пацієнтів із хронічною $\mathrm{CH}$ та анемією. Контрольну групу склали 30 здорових осіб такого ж віку та статі. У всіх обстежених хворих 2 групи діагностовано нормохромну анемію середнього ступеня тяжкості, середній рівень гемоглобіну у них становив $(80,2 \pm 0,12)$ г/л.

Крім загальноприйнятих методів обстеження, усім хворим було проведено оцінку кисневого забезпечення периферійних тканин: визначення сатурації артеріальної (Sa. $\left.\mathrm{O}_{2}\right)$ та венозної $\left(\mathrm{Sv} \mathrm{O}_{2}\right)$ крові, вміст кисню в артеріальній (Са.О2) та венозній (Cv. $\left.\mathrm{O}_{2}\right)$ крові, оцінка об'єму кисню, спожитого периферійними тканинами (Da.O ${ }_{2}-\mathrm{Dv}_{\mathrm{O}} \mathrm{O}_{2}$ ).

Статистичну обробку отриманих результатів виконували за допомогою пакета статистичних програм «Statistica 6.0» (StatSoft, Inc., USA). Параметричні показники оцінювали за критерієм Стьюдента, а непараметричні - за критерієм Манна-Уїтні.

Результати й обговорення. Оцінка параметрів оксигенації артеріальної і венозної крові у хво- рих на хронічну СН (табл. 1) показала, що сатурація артеріальної крові Sa.О 2 знижувалася в міру прогресування захворювання. Зокрема, у обстежених 3 хронічною $\mathrm{CH}$ дане значення було на 5,5 \% $(p<0,05)$ нижчим, порівняно з групою контролю. У групі хворих на хронічну СН виявлено зниження Sa. $\mathrm{O}_{2}$ на 6,2 \% $(p<0,05)$, порівняно з групою контролю. Сатурація венозної крові Sv. ${ }_{2}$ була на 6,8 \% $(p<0,05)$ нижчою, ніж у групі контролю. Значення Sv. $\mathrm{O}_{2}$ у хворих на хронічну СН було нижчим на $6,7 \%$ $(p<0,05)$, порівняно із здоровими особами, а вміст кисню в артеріальній крові Са.О - на 6,1 \% $(p<0,05)$, порівняно з групою контролю. Об'єм спожитого кисню Da. $\mathrm{O}_{2}-\mathrm{Dv} . \mathrm{O}_{2}$ був на $6,0 \%(\mathrm{p}<0,05)$ нижчим у хворих на хронічну $\mathrm{CH}$, порівняно із контрольною групою. Зниження Da.O - Dv. $\mathrm{O}_{2}$ У даної групи пацієнтів можна пояснити зниженням ефективності транспортування кисню до тканин організму і його використання.

Оцінка показників оксигенації артеріальної і венозної крові (див. табл. 1) у хворих 1 та 2 груп показала, що сатурація артеріальної крові Sa.О 2 була нижчою на $5,6 \%(p<0,05)$ у групі пацієнтів із хронічною $\mathrm{CH}$ та анемією, порівняно із хворими 1 групи. Значення Sv. $\mathrm{O}_{2}$ при коморбідності хронічної СН та анемії було нижчим на $14,8 \%$ ( $<<0,01)$, порівняно 3 хворими на хронічну СН. Значення вмісту кисню в артеріальній Сa. $\mathrm{O}_{2}$ і венозній Cv. $\mathrm{O}_{2}$ крові були значимо нижчими у групі пацієнтів з хронічною $\mathrm{CH}$ та анемією, що $є$ свідченням недостатнього насичення киснем периферійних тканин у результаті утруднення трансвенозного кровотоку.

O6'єм спожитого кисню тканинами $\mathrm{Da}^{\circ} \mathrm{O}_{2}-$ Dv. $\mathrm{O}_{2}$ у хворих на хронічну CH та анемію був нижчим на $15,2 \%(p<0,05)$, порівняно з контрольною групою, та на $10,6 \%(p<0,05)$ - порівняно з хворими без анемії. При коморбідності хронічної СН та анемії, зниження об'єму кисню, який транспортується до тканин організму, супроводжується зменшенням об'єму спожитого кисню. Таким чином, прогресує феномен кисневої заборгованості, тоб- 
Огляди літератури, оригінальні дослідження, погляд на проблему, ювілеї то на фоні клінічних ознак прогресування хронічної СН зниження вмісту кисню і насиченості ним

венозної крові можуть слугувати критеріями прогресування основної та коморбідної патології.

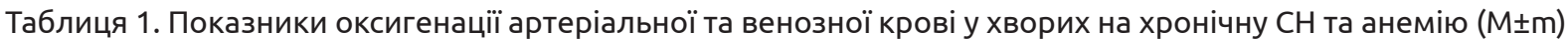

\begin{tabular}{|c|c|c|c|c|}
\hline Показник & $\begin{array}{c}\text { Контрольна група, } \\
\text { n=30 }\end{array}$ & $\begin{array}{c}\text { Хворі на хронічну } \\
\text { СН, } \\
n=36\end{array}$ & $\begin{array}{c}\text { Хворі на хронічну } \mathrm{CH} \\
\text { та анемію, } \\
n=37\end{array}$ & $P_{1-2}$ \\
\hline Sa.O ${ }_{2}$ \% & $98,40 \pm 0,41$ & $94,12 \pm 0,74$ & $92,53 \pm 0,51 *$ & $<0,05$ \\
\hline $\mathrm{Sv} \mathrm{O}_{2}, \%$ & $70,31 \pm 0,33$ & $60,26 \pm 0,41 *$ & $52,64 \pm 0,58 *$ & $<0,01$ \\
\hline 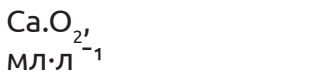 & $149,20 \pm 0,62$ & $140,10 \pm 1,53 *$ & $120,57 \pm 2,65^{*}$ & $<0,01$ \\
\hline $\begin{array}{l}\text { Cv. }{ }_{2 \prime} \\
\text { мл. }{ }^{-1}\end{array}$ & $98,33 \pm 0,62$ & $92,13 \pm 1,41 *$ & $76,75 \pm 2,57^{*}$ & $<0,01$ \\
\hline Da.O - -Dv.O ${ }_{2}$, мл.л ${ }^{-1}$ & $50,96 \pm 0,66$ & $47,97 \pm 0,62$ & $43,82 \pm 0,84^{*}$ & $<0,05$ \\
\hline
\end{tabular}

Примітки: 1. * - достовірність різниці показників порівняно з контролем;

2. р $1-2_{-}$достовірність різниці показників між групами хворих.

Висновки. 1. У хворих на хронічну $\mathrm{CH}$ та анемію виявлено порушення кисневого забезпечення тканин організму, яке проявлялося зниженням сатурації артеріальної крові $\mathrm{Sa}_{2} \mathrm{O}_{2}$ сатурації венозної крові Sv. ${ }_{2}$, вмісту кисню в артеріальній крові Са. $\mathrm{O}_{2}$, вмісту кисню у венозній крові $\mathrm{Cv}_{2} \mathrm{O}_{2}$ та об'єму спожитого кисню периферійними тканинами Da. $\mathrm{O}_{2}-\mathrm{Dv} . \mathrm{O}_{2}$

Виявлений кисневий дефіцит у хворих на хронічну $\mathrm{CH}$ із анемією $є$ свідченням виникнення циркуляторної гіпоксії у даної категорії хворих та потребує відповідної медикаментозної корекції.

\section{ЛІТЕРАТУРА}

1. AHA/ACC Scientific Statement: AHA/ACC guidelines for preventing heart attack and death in patients with atherosclerotic cardiovascular disease: 2001 update: a statement for healthcare professionals from the American Heart Association and the American College of Cardiology / S. C. Jr. Smith, S. N. Blair, R. O. Bonow [et al.] // Circulation. - 2012. - Vol. 114 (10). - P. 385-484.

2. Anemia and mortality in heart failure patients: a systematic review and meta-analisys // H. Groenveld, J. Januzzi, K. Damman [et al.] // J. Am. Coll. Cardiol. - 2016. № 52 (10). - P. 818.

3. Circulating erythropoietin levels and prognosis in patients with congestive heart failure. Comparison with neurohormonal and inflammatory markers / J. George, S. Palat, D. Wexler [et al.] // Arch. Intern. Med. - 2015. -
Vol. 165 (11). - P. 1304-1309.

4. Diagnosis and treatment of acute and chronic heart failure: guidelines / John J. V. McMurray, S. Adamopoulos, S. D. Anker [et al.] // European Heart Journal. - 2014. Vol. 33, No. 14. - P. 1787-1847.

5. ESC Guidelines for the diagnosis and treatment of acute and chronic heart failure. The Task Force for the diagnosis and treatment of acute and chronic heart failure of the European Society of Cardiology (ESC). European Heart Journal 2016, doi: 10.1093/ eurheartj/ehw 128.

6. Heamoglobin level is associated with adverse outcomes in patients with severe chronic heart failure: results from the COPERNICUS study (Abstrac) / S. D. Anker, P. Monasci, A. J. S. Coatis [et al.] // Eur. Heart. J. - 2014. Vol. 24. - P. 487. 
Огляди літератури, оригінальні дослідження, погляд на проблему, ювілеї

\section{REFERENCES}

1. Smith, S.C.Jr., Blair, S.N., \& Bonow, R.O. (2012). AHA/ACC Scientific Statement: AHA/ACC guidelines for preventing heart attack and death in patients with atherosclerotic cardiovascular disease: 2001 update: a statement for healthcare professionals from the American Heart Association and the American College of Cardiology. Circulation, 114 (10), 385-484.

2. Groenveld, H., Januzzi, J., \& Damman, K. (2016). Anemia and mortality in heart failure patients: a systematic review and meta-analysis. J. Am. Coll. Cardiol., 52 (10), 818.

3. George, J., Palat, S., \& Wexler, D. (2015). Circulating erythropoietin levels and prognosis in patients with congestive heart failure. Comparison with neurohormonal and inflammatory markers. Arch. Intern. Med., 165 (11), 1304-1309.
4. John J. V. McMurray, Adamopoulos, S., \& Anker, S.D. (2014). Diagnosis and treatment of acute and chronic heart failure: guidelines. European Heart Journal, 33 (14), 1787-1847.

5. (2016). ESC Guidelines for the diagnosis and treatment of acute and chronic heart failure. The Task Force for the diagnosis and treatment of acute and chronic heart failure of the European Society of Cardiology (ESC). European Heart Journal. doi: 10.1093/ eurheartj/ehw 128.

6. Anker, S.D., Monasci, P., \& Coatis, A.J.S. (2014). Heamoglobin level is associated with adverse outcomes in patients with severe chronic heart failure: results from the COPERNICUS study (Abstrac). Eur. Heart. J., 24, 487.

\title{
НАРУШЕНИЕ КИСЛОРОДНОГО ОБЕСПЕЧЕНИЯ ПЕРИФЕРИЧЕСКИХ ТКАНЕЙ ПРИ АНЕМИИ ХРОНИЧЕСКИХ ЗАБОЛЕВАНИЙ
}

๑А. І. Хоміцька, А. О. Боб, Г. Г. Кміта, Р. Й. Вибирана, Л. Т. Крамар, М. Є. Гаврилюк

гвУз «Тернопольский государственный медицинский университет имени И. Я. Горбачевского МЗ Украины»

Тернопольская университетская больница

РЕЗЮМЕ. В статье приведена оценка показателей оксигенации артериальной и венозной крови у 37 больных с хронической сердечной недостаточностью и анемией. Обоснована целесообразность определения параметров оксигенации артериальной и венозной крови у данной категории больных.

КЛЮЧЕВЫЕ СЛОВА: анемия хронических заболеваний; хроническая сердечная недостаточность; оксигенация артериальной крови; оксигенация венозной крови.

\section{VIOLATION OF OXIDE PROTECTION OF PERIPHERAL TISSUES AT ANEMIA OF CHRONIC DISEASES}

\author{
๑A. I. Khomitska, A. O. Bob, H. H. Kmita, R. Y. Vybyrana, L. T. Kramar, M. Ye. Havryliuk \\ I. Horbachevsky Ternopil State Medical University \\ Ternopil University Hospital
}

SUMMARY. The article evaluated the indexes of oxygenation of arterial and venous blood in 37 patients with chronic heart failure and anaemia. The expediency of applications the definitions of indexes oxygenation of arterial and venous blood in this patients was exhausted.

KEY WORDS: anaemia of chronic diseases; chronic heart faillure; oxygenation of arterial blood; oxygenation of venous blood.

Отримано 8.02.2018 